\title{
CELLULAR FATTY ACID COMPOSITION OF Aeromonas GENUS - DESTRUCTOR OF AROMATIC XENOBIOTICS
}

\author{
T. V. GUDZENKO ${ }^{凶}$, O. G. GORSHKOVA, N. V. KOROTAIEVA, \\ O. V. VOLIUVACH, A. M. OSTAPCHUK, V. O. IVANYTSIA \\ Odesa I. I. Mechnikov National University, Ukraine; \\ ${ }^{\natural-m a i l: t g u d z e n k o @ u k r . n e t ~}$
}

Received: 17 September 2018; Accepted: 13 December 2018

The aim of this study was a determination of the fatty acid composition of cellular lipids and identification of the strains, isolated from the wastewater of pharmaceutical production, - the destructor of aromatic xenobiotics. The phenotypic characteristics and cellular fatty acid (FA) composition confirmed the strain belonging to the Aeromonas ichthiosmia with the similarity index of library data MIDI Sherlock - 0.564. Analysis of the cellular FA composition of the strain Aeromonas ichthiosmia ONU552 was carried out using the MIDI Sherlock microorganism identification system based on the gas chromatograph Agilent 7890. Chromatographic analysis showed that the fatty acid profile of the strain Aeromonas ichthiosmia ONU552 contains 26 fatty acids with the total number of carbon atoms from 10 to $18.85 .27 \%$ of saturated and unsaturated fatty acids had unbranched structure. The total content of unsaturated fatty acids - 16:1 w7c/16:1 w6c, 18:1 w7c, 16:1 w7c alcohol, 17:1 w8c, 17:1 w6c, 16:1 w5c, was 50\% of the total fatty acid pool. Less than 1.5\% branched fatty acids were predominantly in the iso form: 13:0 iso (0.20\%); 15:0 iso (0.97\%); 17:1 iso w9c (1.35\%), 17:0 iso (1.49\%); in the anteiso form, only one acid 17:0 (0.27\%) was identified. It was shown that the characteristic of the fatty acid composition of the strain Aeromonas ichthiosmia ONU552 - the destructor of aromatic xenobiotics, was the presence of hydroxyacids 12:0 3OH, 15:0 3OH, 15:0 iso 3OH and dominance of hexadecanoic (16:0) and hexadecenoic (16:1 w7c/16:1 w6c) of fatty acids.

Ke y wo rds: Aeromonas ichthiosmia, destructor of aromatic xenobiotics, cellular fatty acid composition.

$\mathrm{B}$ acteria of the genus Aeromonas are inhabitants of fresh, marine and sewage waters. Aeromonads are often isolated from drainage collectors and reclamation. They have a wide range of destructive activity with respect to organic xenobiotics. It is known that representatives of the genus Aeromonas constitute approximately $2 \%$ of the total biomass of activated sludge. They are presented as biofilms and aggregates so they are resistant to extreme conditions of $\mathrm{pH}$, salinity, heavy metals and temperature [1]. Among the bacteria of the genus Aeromonas are pathogens for cold-blooded animals (fish and amphibians) [1-4].

The destructive properties of the bacteria of the genus Aeromonas with respect to toxic phenolic and other difficult oxidation compounds are shown [5-9]. It was found that the strain Aeromonas hydrophila sp. K, isolated from contaminated soil, the biodegradation of benzyldimethylalkylammonium chloride (BAC) by, that and capable of using $\mathrm{BAC}$ as the sole source of carbon and energy [5]. Kumar S.S. and others pointed to the high biochemical activity of a strain also belonging to the species Aeromonas hydrophila. For bioremediation of wastewater containing hardly oxidizable textile azo dyes, it was suggested to use Aeromonas hydrophila KF032718. Analogues of infrared spectroscopy Fourier (FTIR) confirmed biotransformation of textile azo dyes, including Joyfix Red [6]

Aeromonas spp is as part of the consortium of microorganism-destructors (Bacillus sp., Aeromonas sp., Alcaligenes eutrophus, Alcaligenes denitrificans), which are used to clean soil and water from oil contamination [7]. The strain Aeromonas salmoni-

(C) 2019 Gudzenko T. V. et al. This is an open-access article distributed under the terms of the Creative Commons Attribution License, which permits unrestricted use, distribution, and reproduction in any medium, provided the original author and source are credited. 
cida NY4 - the destructor of polycyclic aromatic hydrocarbons was isolated from wastewater sludge [8]. Hohzoh Kiyohara et al. suggested that the phenanthrene-assimilating bacteria of the genus Aeromonas degrade phenanthrene via o-phthalate [9].

In previous studies, a strain of bacteria-destructors of phenolic compounds was isolated from the wastewater of pharmaceutical production [10], also it was identified by phenotypic characteristics as the species Aeromonas ichthiosmia [3].

The aim of this study was determination of fatty acid composition of cellular lipids and identification of the strains, isolated from the wastewater of pharmaceutical production, - the destructor of aromatic xenobiotics.

\section{Materials and Methods}

The object of research was a strain it was isolated from the wastewater of pharmaceutical production and that it is biochemically active against phenolic compounds.

For analysis of the cellular fatty acids composition of the strain inoculation loops of biomass (the bacteria were cultured on Tryptic soy agar medium at the temperature of $28 \pm 1^{\circ} \mathrm{C}$ for $24 \mathrm{~h}$ ) were placed into glass vials for chemical cell lysis and saponification of lipids. Saponification of bacterial cellular lipids was conducted with methanol solution of $\mathrm{NaOH}$, methylation of fatty acid salts was conducted with acidic methanol solution, extraction was performed with organic solvent by liquid-liquid extraction and neutralization of the sample was achieved with $0.1 \mathrm{M} \mathrm{NaOH}$ treatment. The obtained methyl esters were analyzed by gas chromatography [11].

Methyl esters of cellular fatty acids were separated on gas chromatograph Agilent 7890 (Agilent Technologies, USA) with ULTRA-2 capillary column and with flame-ionization detector (FID). In the course of analysis, a samples of bacterial material with a volume of $2 \mu \mathrm{l}$ volume were transferred into the evaporator in the mode split with a coefficient 40:1, evaporator's temperature $-250{ }^{\circ} \mathrm{C}$. The separation was carried out in temperature programming mode - initial temperature of $170{ }^{\circ} \mathrm{C}$ with a gradient of $5{ }^{\circ} \mathrm{C} / \mathrm{min}$ to $270{ }^{\circ} \mathrm{C}$. Fatty acid content was expressed as a percentage to total sum of peaks' squares.

Determination of the cellular fatty acid composition of the strain and identification were performed using the MIDI Sherlock 4.5 software and the RSTBA6 library version 6.2.
Statistical processing of the results of studies conducted three times, was carried out using the MS Excel computer program with the definition of Student's $t$-test. The difference was considered statistically significant at $P<0.05$.

\section{Results and Discussion}

Based on the phenotypic characteristics that it was determined by classical bacteriological methods and by the API 50 CHB Medium test system (bioMerieux, France), the explored strain was previously classified as Aeromonas ichthiosmia. It is shown that the strain Aeromonas ichthiosmia ONU552 is a gram-negative mobile rod with a size of 1.0-3.0 $\times 0.4$ $1.0 \mu \mathrm{m}$. Bacteria are catalase- and oxidase positive, reduce nitrates, are DNA-like active and resistant to $\mathrm{O} / 129$ (2,4-diamino-6,7-diisopropylpteridine phosphate), produce indole. The strain Aeromonas ichthiosmia ONU552 has a positive reaction with methyl red and a positive reaction of Foges-Proskauer, does not produce hydrogen sulphide, does not ferment lactose. It ferments glucose (with the synthesis of acid and gas), arabinose, sucrose. The metabolism of the strain Aeromonas ichthiosmia ONU552 is characterized by oxidation and fermentation.

The cellular fatty acid composition of the strain Aeromonas ichthiosmia ONU552 is presented in Table. Chromatography analysis showed that the cellular fatty acid composition of the strain Aeromonas ichthiosmia ONU552 contains saturated and unsaturated isomers of fatty acids with the total number of carbon atoms from 10 to 18 (Figure, Table). The total percent of the fatty acid 16:1 was $36,89 \%, 16: 0-$ $21.84 \%$, the presence of the isomer was $18: 1$ w7c was $8.53 \%, \Sigma 14: 03 \mathrm{OH} / 16: 1$ iso $-6.59 \%, 12: 0-6.4 \%$, $15: 0$ iso $3 \mathrm{OH}-3.85 \% 14: 0-3.77 \%$. The amount of isomers 13:0, 14:0, 18:0 was less than $1 \%$.

The total content of unsaturated fatty acids, including those found in minor amounts, was 50\% of the total fatty acid pool of the strain Aeromonas ichthiosmia ONU552 ( $216: 1 \mathrm{w} 7 \mathrm{c} / 16: 1 \mathrm{w} 6 \mathrm{c}$ (36.89\%), $18: 1 \mathrm{w} 7 \mathrm{c}(8.53 \%), 16: 1 \mathrm{w} 7 \mathrm{c}$ alcohol $(3.45 \%), 17: 1 \mathrm{w} 8 \mathrm{c}$ $(0.60 \%), 17: 1 \mathrm{w} 6 \mathrm{c}(0.26 \%), 16: 1 \mathrm{w} 5 \mathrm{c}(0.12 \%))$. It is interesting to note that, as it was studied, the fatty acid profiles of other destructors of phenol compounds (Bacillus subtilis $\mathrm{F}-13$, Brevibacillus centrosporus F-14) isolated from the wastewater of pharmaceutical production, 16:1 w7c alcohol was also discovered and the molar fraction of them varied from $1.08 \%$ in Bacillus subtilis $\mathrm{F}-13$ to $7.71 \%$ in Brevibacillus centrosporus F-14 [10, 12]. 


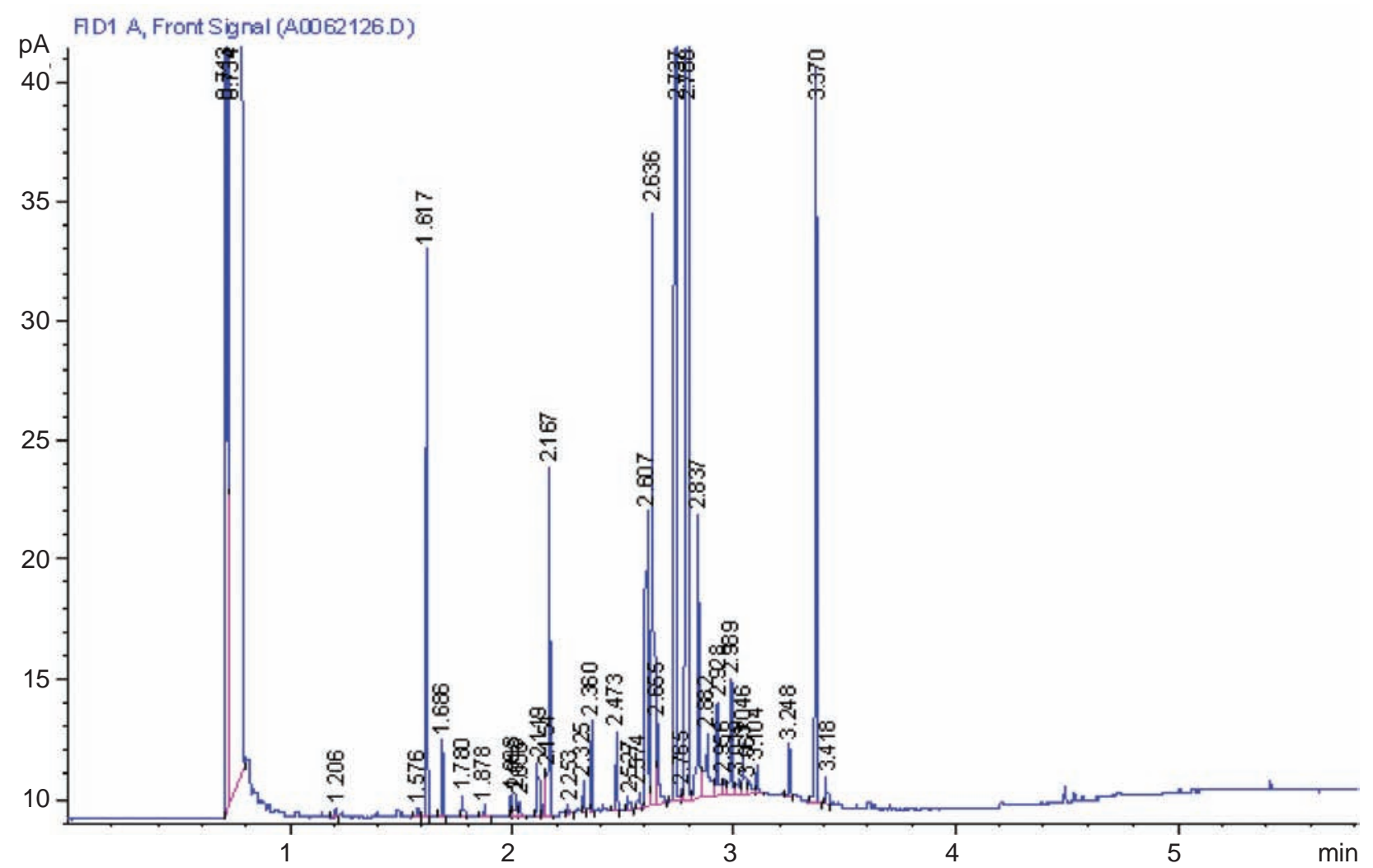

Chromatogram of cellular fatty acids of Aeromonas ichthiosmia ONU552

The peculiarity of the strain Aeromonas ichthiosmia ONU552, the destructor of aromatic xenobiotics, turned out to be the presence of monounsaturated 9-hexadecenoic (16:1 w7c) and 10-hexadecenoic (16:1 w6c) acids, which amounted to a maximum percentage of $36.89 \%$ from cellular fatty acids composition. The found features of the fatty acid composition of the bacterial strain Aeromonas ichthiosmia ONU552 under investigation can be associated with the predominant content of organic

Cellular fatty acid (\%) composition of Aeromonas ichthiosmia ONU552

\begin{tabular}{|c|c|c|c|}
\hline Fatty acid & $\%$ of the total peak areas & Fatty acid & $\%$ of the total peak areas \\
\hline $10: 0$ & 0.17 & $\sum 16: 1 \mathrm{w} 7 \mathrm{c} / 16: 1 \mathrm{w} 6 \mathrm{c}$ & 36.89 \\
\hline 12:0 & 6.94 & $16: 1 \mathrm{w} 5 \mathrm{c}$ & 0.12 \\
\hline $12: 03 \mathrm{OH}$ & 0.23 & 16:0 & 21.84 \\
\hline $13: 0$ iso & 0.20 & $17: 1$ iso $w 9 c$ & 1.35 \\
\hline 13:0 & 0.15 & $17: 0$ iso & 1.49 \\
\hline 14:0 & 3.77 & 17:0 anteiso & 0.27 \\
\hline$\sum 14: 03 \mathrm{OH} / 16: 1$ iso I & 6.59 & $17: 1$ w8c & 0.60 \\
\hline $15: 0$ iso & 0.97 & $17: 1$ w6c & 0.26 \\
\hline $15: 0$ iso $3 \mathrm{OH}$ & 3.85 & $17: 0$ & 0.33 \\
\hline $15: 03 \mathrm{OH}$ & 0.35 & $18: 1 \mathrm{w} 7 \mathrm{c}$ & 8.53 \\
\hline 16:1 w7c alcohol & 3.45 & 18:0 & 0.30 \\
\hline 16:0 $\mathrm{N}$ alcohol & 1.34 & & \\
\hline
\end{tabular}

Note: dominant fatty acids are marked in bold 
pollutants in the wastewater produced by pharmaceutical preparations.

The absence in the fatty acid profile of the strain Aeromonas ichthiosmia ONU552 of branched fatty acid-12-methyltetradecanoic acid (15:0 anteiso) and the presence of a small amount of 13-methyltetradecanoic acid (15:0 iso, $0.97 \%)$ significantly distinguished this strain from bacteria-destructors of other taxonomic groups, including the genus Brevibacillus, in which the branched fatty acids were represented by $15: 0$ iso $(9.59-43.91 \%)$ and $15: 0$ anteiso (20.55-74.46\%) [13]. According to the literature, various stress factors such as presence of xenobiotics or heavy metal salts, high temperature, low $\mathrm{pH}$ may be inductors of fatty acid isomerization [14].

The biomarker ratio of fatty acids 17:0 of the branched structure of 15-methylhexadecanoic acid to 14 -methylhexadecanoic acid (17:0 iso (1.49\%)/17:0 anteiso (0.27\%)) for strain Aeromonas ichthiosmia ONU552 was 5.51 .

The presence of a large number of branched fatty acids in the cellular lipid composition was not typical for the strain Aeromonas ichthiosmia ONU552. Branched fatty acids, preferably in the form of iso: $-13: 0$ iso $(0.20 \%)$ 15:0 iso $(0.97 \%)$; $17: 1$ iso w9c $(1.35 \%), 17: 0$ iso $(1.49 \%)$ were detected in the amount of less than $1.5 \%$ (excluding the hydroxy acid 15:0 iso $3 \mathrm{OH}, 3.85 \%$ ). Only one acid 17:0 $(0.27 \%)$ was recorded in the form - anteiso.

It was compared the obtained data on the cellular fatty acids composition of the strain Aeromonas ichthiosmia ONU552 with other representatives of the genus Aeromonas [15] and it was noted that almost all the characteristic fatty acids of the genus Aeromonas were in the strain Aeromonas ichthiosmia ONU552 (13:0 iso, 17:0, 17:1 w8c, 15:0 iso, 17:0 iso, $17: 1 \mathrm{w} 9 \mathrm{c}$ iso), with the exception of such fatty acids as 15:0, 16:0 iso; and it was found instead of 16:1 w9c alcohol to $16: 1 \mathrm{w} 7 \mathrm{c}$ alcohol.

Comparison of the literature data on the fatty acid profile of the strain Aeromonas hydrophila ATCC 35654 with the obtained data of fatty acid profile of the strain Aeromonas ichthiosmia ONU552 has proved certain similarities: the presence of almost identical percentage of isomers (36\% of the total area of the peaks in the chromatogram) of hexadecenoic acids (16:1 w7c/16:1 w6c) and the presence a slightly higher percent of hexadecanoic acid in the Aeromonas ichthiosmia ONU552 strain (21.84\%) compared to the Aeromonas hydrophila ATCC 35654 (17.29\%). Conversely, it was found out that strain Aeromonas ichthiosmia ONU552 contains less fatty acid 18:1 w7c (8.53\%) compared with the strain Aeromonas hydrophila ATCC 35654. However, 15:0; $\Sigma 14: 03 \mathrm{OH} / 16: 1$ iso I; $16: 1 \mathrm{w} 7 \mathrm{c}$ alcohol and 16:0 $\mathrm{N}$ alcohol fatty acids are not present in fatty acid profile of the strain Aeromonas hydrophila ATCC 35654 [16].

It was interesting to observe the similarity of the fatty acid composition of the strain Aeromonas ichthiosmia ONU552 and the strain Aeromonas sharmana sp. nov. GPTSA-6T [17]. Fatty acids 16:0, 18:1 w7c, 12:0, 14:0 and total $\Sigma 14: 03 \mathrm{OH} / 16: 1$ iso were detected on chromatograms of both bacterial strains. So, the strain Aeromonas ichthiosmia ONU552 that was investigating during the study is similar to the strain Aeromonas sharmana sp. nov. GPTSA-6T according to the fatty acid profile.

The ratio of the total number of saturated and unsaturated fatty acids of the unbranched structure to the total amount of fatty acids of the branched structure was 10.5 .

There were 3-hydroxydodecanoic ( $0.23 \%)$ and 3-hydroxypentadecanoic $(0.35 \%)$ acid in the lipid fractions of the strain Aeromonas ichthiosmia ONU552 - destructor of aromatic xenobiotics. In addition, it was fixed fatty acid 15:0 iso $3 \mathrm{OH}$ with a percent content of 3.85 (Table). The total amount of hydroxy acids was $11.02 \%$ of the total fatty acids percent of the strain Aeromonas ichthiosmia ONU552.

Thus, the analysis of the cellular fatty acid profile of the strain of the bacterium destructor of aromatic xenobiotics using the MIDI Sherlock system showed that the presence of hydroxy acids $(12: 03 \mathrm{OH}, 15: 03 \mathrm{OH}, 15: 0$ iso $3 \mathrm{OH})$ and the dominance of hexadecanoic (16:0) and hexadecenoic (16:1 w7c/16:1w6c) acids were a feature of the strain of the Aeromonas ichthiosmia ONU552. The similarity index of the strain Aeromonas ichthiosmia ONU552 to species of Aeromonas ichthiosmia was 0.564.

The revealed features of the fatty acid composition of the strain Aeromonas ichthiosmia ONU552 destructor of aromatic xenobiotics are important for control of the bacterial culture in the manufacturing of biological products intended for purification of sewage from production of pharmaceuticals, which contain biological contaminants, toxic and other heavy oxidation compounds.

Conflict of interest. Authors have completed the Unified Conflicts of Interest form at http:// ukrbiochemjournal.org/wp-content/uploads/2018/12/ coi_disclosure.pdf and declare no conflict of interest. 


\section{СКЛАД ЖИРНИХ КИСЛОТ ЛІПІДІВ БАКТЕРІЙ РОДУ Aeromonas - ДЕСТРУКТОРА АРОМАТИЧНИХ КСЕНОБІОТИКІВ}

\author{
Т. В. Гудзенко , О. Г. Горикова, \\ Н. В. Коротаєва, О. В. Волювач, \\ A. М. Остапчук, В. О. Іваницяя
Одеський національний університет імені I. I. Мечникова, Україна; 凶e-mail: tgudzenko@ukr.net

Метою роботи було визначення складу жирних кислот клітинних ліпідів та ідентифікація штаму, ізольованого із стічної води виробництва фармацевтичних препаратів, - деструктора ароматичних ксенобіотиків. За фенотиповими ознаками і складом жирних кислот клітинних ліпідів підтверджено приналежність досліджуваного штаму до виду Aeromonas ichthiosmia з індексом подібності жирнокислотного профілю 3 бібліотечними даними MIDI Sherlock - 0,564. Аналіз складу жирних кислот штаму Aeromonas ichthiosmia ONU552, виділеного зі стічної води виробництва фармацевтичних препаратів, здійснювали 3 використанням автоматичної системи ідентифікації мікроорганізмів MIDI Sherlock на базі газового хроматографа Agilent 7890. Показано, що в жирнокислотному профілі бактерій досліджуваного штаму Aeromonas ichthiosmia ONU552 були присутні жирні кислоти (26) із загальним числом атомів вуглецю від 10 до 18. Загальна кількість насичених і ненасичених жирних кислот нерозгалуженої будови дорівнювала 85,27\%. Сумарний вміст ненасичених жирних кислот становив 16:1 w7c/16:1 w6c, 18:1 w7c, 16:1 w7c alcohol, 17:1 w8c, 17:1 w6c, 16:1 w5 - тобто 50\% від всього жирнокислотного пулу. Виявлено $1,5 \%$ розгалужених жирних кислот, переважно у формі -iso - 13:0 iso $(0,20 \%) ; 15: 0$ iso $(0,97 \%)$; $17: 1$ iso $\mathrm{w} 9 \mathrm{c}(1,35 \%), 17: 0$ iso $(1,49 \%)$; $\mathrm{y}$ формі - anteiso зафіксовано тільки одну кислоту 17:0 (0,27\%). Таким чином, особливістю жирнокислотного складу штаму бактерій Aeromonas ichthiosmia ONU552 - деструктора ароматичних ксенобіотиків - $€$ наявність гідроксикислот 12:0 3ОH, 15:0 3OH, 15:0 iso $3 \mathrm{OH}$ і домінування гексадеканової (16:0) і гексадеценової $(16: 1$ w7c/16:1 w6c) жирних кислот.
К л ю ч о в і с ло в а: Aeromonas ichthiosmia, деструктор ароматичних ксенобіотиків, склад жирних кислот ліпідів.

\section{References}

1. Talagrand-Reboul E, Jumas-Bilak E, Lamy B. The social life of Aeromonas through biofilm and quorum sensing systems. Front Microbiol. 2017; 8: 37.

2. Ljungh A, Wadström T. Aeromonas toxins. Pharmacol Ther. 1981; 15(3): 339-354.

3. Bergey's Manual ${ }^{\circledR}$ of Systematic Bacteriology. Eds.: Brenner DJ, Krieg NR , Staley JT, Garrity GM. N.Y.: Springer, 2005; 2: 1108 p.

4. Romero A, Saraceni PR, Merino S, Figueras A, Tomás JM, Novoa B. The animal model determines the results of Aeromonas virulence factors. Front Microbiol. 2016; 7: 1574.

5. Patrauchan MA, Oriel PJ. Degradation of benzyldimethylalkylammonium chloride by Aeromonas hydrophila sp. K. J Appl Microbiol. 2003; 94(2): 266-272.

6. Kumar SS, Shantkriti S, Muruganandham T, Murugesh E, Rane N, Govindwar SP. Bioinformatics aided microbial approach for bioremediation of wastewater containing textile dyes. Ecol Inform. 2016; 31: 112-121.

7. Pat. 2182529 RF, MPK 7B 09C 1/10 A, 7C $02 \mathrm{~F} 3 / 34 \mathrm{~B}, 7 \mathrm{C} 12 \mathrm{~N} \mathrm{1/26} \mathrm{B}$. Consortium of microorganism-destructor strains: Bacillus spp, Aeromonas spp., Alcaligenes eutrophus, Alcaligenes denitrificans, used for cleaning soils, soils and waters from oil pollution / G. P. Golodjaev. Publ. 2002.

8. Nie M, Nie H, Cao W, Wang X, Guo Y, Tian X, Yin X, Wang Y. Phenanthrene metabolites from a new polycyclic aromatic hydrocarbondegrading bacterium Aeromonas salmonicida subsp. achromogenes strain NY4. Polycycl Aromat Compd. 2016; 36(2): 132-151.

9. Kiyohara H, Nagao K, Nomi R. Degradation of phenanthrene through o-phthalate by an Aeromonas sp. Agric Biol Chem. 1976; 40(6): 1075-1082.

10. Application for utility model U201804337 UA, MPK S 02F1/72. Methods of microbiological purification of water from phenol and N-cetylpyridinium bromide / Ivanytsia V. O., Hudzenko T. V., Horshkova O. H., Voliuvach O. V., Konup I. P., Bieliaieva T. O., Drahunovska O. I.; appl. 20.04.2018. 
11. MIS Operating Manual. www.midi-inc.com, September 2012.

12. Gorshkova OG, Shtenikov MD, Korotaeva NV, Voliuvach OV. Features of fatty strength profile of strain Brevibacillus centrosporus F14 destructor of phenolic compounds. Ukr Biochem J. 2018; 90(3): 134.

13. The role of microorganisms in the functioning of living systems: fundamental problems and bioengineering applications. Eds.: V. V. Vlasova, A. G. Degermendzhi, N. A. Kolchanova, V. N. Parmona, V. E. Repina. Novosibirsk: SO Russ Akad Nauk, 2010; (28): 476 p.

14. Heipieper HJ, Meulenbeld G, van Oirschot Q, de Bont J. Effect of environmental factors on the trans/cis ratio of unsaturated fatty acids in Pseudomonas putida S12. Appl Environ Microbiol. 1996; 62(8): 2773-2777.

15. Huys G, Vancanneyt M, Coopman R, Janssen P, Falsen E, Altwegg M, Kersters K. Cellular fatty acid composition as chemotaxonomic marker for the differentiation of phenospecies and hybridization groups in the genus Aeromonas. Int J Syst Bacteriol. 1994; 44(4): 651-658.

16. Morey A, Oliveira ACM, Himelbloom BH. Identification of seafood bacteria from cellular fatty acid analysis via the Sherlock ${ }^{\circledR}$ microbial identification system. J Biol Life Sci. 2013; 4(2): 139-153.

17. Saha P, Chakrabarti T. Aeromonas sharmana sp. nov., isolated from a warm spring. Int J Syst Evol Microbiol. 2006; 56(Pt 8): 1905-1909. 